\title{
Optimization of process parameters for production of bottle gourd powder
}

\section{SMITA KHODKE, KARUNA SHINDE AND PRAMODINI MORE}

Received : 04.03.2014; Revised : 30.07.2014; Accepted : 13.08.2014

See end of the Paper for authors' affiliation

Correspondence to :

\section{SMITA KHODKE}

Department of Agricultural Process Engineering, College of Agricultural Engineering and Technology (V.N.M.K.V.), PARBHANI (M.S.) INDIA Email : sukhodke@ rediffmail.com
ABSTRACT : The bottle gourd is having tremendous health benefits. However, process of consuming fresh bottle gourd to meet daily recommended requirement is tedious. The easy way is to consume bottle gourd in powder form which also avoids pains and drudgery involved in its daily processing. This can help to make it available as and when required. But there is no standard process available for the preparation of bottle gourd powder having optimum quality attributes. Hence, the study was undertaken to find out the effect of different pretreatment such as steam blanching time and drying air temperature on the quality attributes of bottle gourd powder. Bottle gourd powder was prepared by varying process parameters viz., steam blanching time $(2,4,5$ and $8 \mathrm{~min})$ and drying air temperature $\left(50,60,70\right.$ and $\left.80^{\circ} \mathrm{C}\right)$ and compared with treatment without blanching. Quality attributes of bottle gourd powder such as bulk density, water absorption capacity, ascorbic acid and potassium were determined. Sensory evaluation of bottle gourd powder was performed. Steam blanching pretreatment $(6 \mathrm{~min})$ prior to hot air drying $\left(60^{\circ} \mathrm{C}\right)$ was found to be the most effective to obtain better quality bottle gourd powder. The bottle gourd powder prepared by the developed process technology was highly consumer acceptable.

- KEY WORDS : Bottle gourd powder, Steam blanching, Ascorbic acid, Potassium

ם HOW TO CITE THIS PAPER : Khodke, Smita, Shinde, Karuna and More, Pramodini (2014). Optimization of process parameters for production of bottle gourd powder. Internat. J. Agric. Engg., 7(2) : 328-333. 